\title{
Dual Semantics of the Latin inter(-)*
}

\author{
Evgeniy G. Filimonov
}

Saint Petersburg State University,

7-9, Universitetskaya nab., St. Petersburg, 199034, Russian Federation; evfilimonov@yandex.ru

For citation: Evgeniy G. Filimonov. Dual Semantics of the Latin inter(-). Philologia Classica 2019, 14(1), 84-88. https://doi.org/10.21638/11701/spbu20.2019.106

The paper analyzes the function of the prefix inter-, which allows to reduce the 15 main senses (described in the $O L D$ ) to the basic two. The sense of the prefix depends on the situation described with the compound: a) the situation of dividing space: 'a border between two or more points disconnecting them' (inter hostes flumen erat). Most of the verbs in this group are transitive and accompanied by a countable object: intercalare 'to insert a day or month into the calendar'; interloqui 'to interrupt, to speak between'. b) the situation of connected space: 'all the space (or time) between two points connecting them within the same situation' (inter arma tacent musae). The majority of these verbs are transitive and are used with an uncountable object: interbibere 'to drink dry, drain'; interlegere 'to pick off here and there, to thin'. Some verbs can have either sense depending on the context (interesse: a. 'to lie between, intervene' modo inter me atque te murus intersit (Cic. Cat. 1. 10.), b. 'to be in the company of, to take part' legit scripta de se carmina, legit historias, et posteritati suae interfuit (Plin. Ep. 2.1.2). On the basis of this classification principle four verbs are analyzed in which the meaning of the prefix inter-is unclear: interire, interficere, interimere, intellegere. Three of them have the prefix inter- in the sense of division and form pairs of compounds (an intransitive verb of state interire - a verb of action interimere, interficere). The verb intellegere has two senses as different stages of its semantic development: 1. 'to choose between', 'to notice, discern' and 2. 'to collect together (all the parts)' > 'to grasp, understand (the whole picture of an object or a situation)'.

Keywords: historical grammar of Latin, Latin etymology, Latin lexicology.

\section{Reducing the meaning of inter to two basic senses}

I propose an alternative structure of basic senses of the Latin preposition (and prefix) inter(-) instead of that in the OLD, which describes 15 senses of the preposition inter. I suggest that most of them are in fact contextual modifications of the two basic senses either a) a border between two or more points disconnecting them (inter hostes flumen erat) or b) all the space (or time) between (within or among) two points connecting them within the same situation (inter arma tacent musae).

* I would like to thank M. M. Pozdnev and E. V.Zheltova for numerous valuable comments and suggestions they made on the draft of the paper.

(C) St. Petersburg State University, 2019 


\subsection{The basic sense of inter- describing a situation of division (group a)}

To make the analysis less complicated I assume that the prefix inter- in the transitive verbs has the same two senses as the preposition: a) a border between two objects (or interruption within a process)' $:^{1}$

(1) intercalare 'to insert (a day or month) into the calendar': (< calare 'to announce, proclaim') posterior dies kalendarum intercalatur (Ulp. Dig. 4.4.3.3.)

(2) intercludere 'to make impassable, block, cut': omnis aditus ad Sullam intercludere (Cic. S. Rosc. I 10.)

(3) intercìdere 'to cut through, sever': lacus Velinus... interciso monte in Nar defluit (Cic. Att. 4.15.5.) (the intransitive parallel - intercidere 'to fall between, perish').

(4) intercipere 'to seize or catch in transit, cut off from its destination, intercept': tun redimes me, si me hostes interceperint (Pl. As. 106.).

(5) interdare 'interpose in time or in space': nec mora nec requies interdatur ulla fluendi (Lucr. 4 227.)

(6) intercinere 'to sing between or in the interval of': neu quid medios intercinat actus (Hor. AP 194.)

(7) intervenire 'to arrive during the course of an activity, come on the scene', 'to drop in or break in (on a person)': pro Iuppiter! — quid est? - sponsae pater intervenit (Ter. An. 732.)

(8) interfari 'to interrupt (a speaker)': priusquam... ille postulatum perageret... Appius interfatur (Liv. 3.47.4.)

(9) interpellere 'to interrupt, to impede': cuius orationem Caesar interpellat (Caes. BCiv. 1. 22. 5.)

(10) interloqui 'to interrupt, to speak between': permitte mihi aliquid interloqui (Sen. Ben. 4. 26.1.)

(11) interdicere 'to forbid': interdicere alicui aqua et igni (inter-can be interpreted here as 'to interrupt something by speaking, to obstruct, get in the way of', the original meaning of the syntactic construction: to speak in order to bar somebody from using water and fire). It can be objected that the Romans did not perceive interdicere as a compound at all, but I think they did because inter- expresses here a kind of an interruption (cf. the usage of such verbs as interpellere and interponere that mean 'to intervene in order to forbid').

1.2. The basic sense of inter- describing a situation of connected space (group b): the whole space (or time) between two points in the same environment or space in which a certain process is taking place:

(12) interbibere 'to drink dry, drain': mare interbibere (Naev. Trag. 52.)

(13) interlegere 'to pick off here and there, to thin': uncis carpendae manibus frondes interque legendae (Verg. G. 2.366.) (cf, also two synonymous verbs intervellere and interputare).

(14) interrogare 'to ask' in testibus interrogandis (Cic. Verr. 1.29.) (inter- expresses here a reciprocal action of conversation as a whole process).

(15) interradere 'to decorate with incised carving or intaglio': interradimus alia (vasa) ut quam plurimum lima perdiderit (Plin. HN.33.140.)

\subsection{Verbs which express either sense depending on the context (group c):}

(16) interesse has both senses: a 'to lie between, intervene': modo inter me atque te murus intersit (Cic. Cat. 1. 10.), 'to constitute a difference': multum interest inter hoc dicendi genus et superiora (Cic. Orat. 98.) and b. 'to be in the company of, to take part' legit scripta de se carmina, legit historias, et posteritati suae interfuit (Plin. Ep. 2.1.2).

1 The list of the verbs is not exhaustive and serves for the purpose of exemplification. 
(17) intercurrere a. 'to occur': intercurrunt quaedam stellae... nobis novae (Sen. QNat. 7.13.1. and b. 'to extend between, mediate': latitudine intercurrentis freti (Plin. HN . 3.100.)

(18) interlucere a. 'to have gaps': qua rara est acies interlucetque corona non tam spissa viris (Verg. Aen. 4. 9. 508.) b. 'to be manifest' (of differences): dissimilis forma atque natura loci comparandi sunt, ut distincti interlucere possint (Rhet. Her. 3. 31.)

(19) intercedere a. 'to divide': planities inter utraque castra intercedebat BHisp. 29.1. and b. 'to be, exist' magna inter nos officia paria et mutua intercedunt (Cic. Fam. 13.65.1.)

\subsection{Verbs which do not express either of the two senses (group d):}

(20) interimere 'to kill': hunc veprem manifestum est interimi non posse (Plin. HN. 2.3.7.) (intransitive parallel - interire 'to die, perish').

(21) interficere 'to kill': cuius pater...ab civitate erat interfectus (Caes. BGal. 7.4.1); nam vita humana prope uti ferrum est. Si exerceas, conteritur; si non exerceas, tamen rubigo interficit (Cato Mor. $3(\mathrm{~J})$ ). (intransitive parallel — interfieri 'to die, perish').

(22) interire 1. (of living things) 'to die, perish, be killed', 'to die out, become extinct': ut ego hanc familiam interire cupio (Plaut. Poen. 870.); non interire animas, sed... transire ad alios (Caes. BGal. 7.71.3.). 2. (of material things) 'to be destroyed, disappear': ne forte credas interitura, quae verba loquor (Hor. Carm.4.9.1).

(23) intellegere 1.'to discern, recognize' (form, colour, taste or other physical characteristics). 2. 'understand' (see the examples below, in $₫ 2.2$.).

\section{The semantic structure of the pair interimere 'to kill' - interire 'to die'}

The Group d. consists of the verbs some of which trace back to Indo-European times because they have exact Indo-European parallels. Their age and hence the peculiarity of the situation they describe can make a false impression that inter-as their element expresses neither sense a., nor sense $b$. Nonetheless it is plausible that inter-in the examples (20-22) represents the sense a. 'a dividing barrier between two points'. The definition in $O L D$ for interimere 1. 'to cut off from life, kill' speaks for this explanation. ${ }^{2}$

\subsection{The semantic structure of the verb interficere 'to kill'}

The Lat. interficere 'to kill' as well as interimere 'to kill' builds the transitive parallel to the intransitive interire and perire 'to die'. The same semantic relationship between a verb of 'coming into a state' and a verb which causes this state - such verbal pairs as interìre 'to die' and interficere 'to kill' - exists in other I.-E.languages, e. g. Skr. antar-gam (lit. 'in the middle, between'-'go') 'disappear' (Apte 1957, 124) - antar-dha 'to kill, destroy' (lit. 'in the middle, between'-'put') (Mayrhofer 1992, 76) = inter-ficere = per-dere. In sum, the verbs interficere 'to kill' and conficere 'to kill' can describe a situation in which the direct object disappears as a result of the action while the verb perficere 'to complete' describes a situation as a result of which the direct object completes its quality without going away.

2 M. M. Pozdnev proposed a Greek parallel ảvaıpeĩ $\theta$ aı 'to take up', 'to kill' and a convincing German semantic parallel: umgehen - umbringen, which is similar to perire (interfiere) - interficere. 


\subsection{The semantic structure of the verb intellegere 'to understand'}

The etymology of intellegere (23) is not clear at all (see a different interpretation by Kümmel 2001, 276). I will only give some suggestions based on the classical etymology of the verb which connects it to the Lat. legere 'collect' (Ernout-Meillet 2001, 348-350) and (Walde-Hoffmann 1938, 780). It has the sense of the type a. 'to discern, recognize (form, colour, taste or other physical characteristics)', 'to distinguish mentally, recognize as existing', as well as the type b. sense - 'to grasp mentally, understand, realize.' The two senses do not contradict each other. The ultimate etymological sense must have been sense a. 'to discern, recognize (form, colour, taste or other physical characteristics)' which is expressed by inter - the comparative form of the adverb in (that later came to be felt as a prefix). Ernout-Meillet (2001, 348-350) and Walde-Hoffmann (1938, 780) assume inter- in the sense a., i. e. 'to choose between' with the further semantic development into 'to notice, discern' and 'to understand'. An alternative solution would be to reconstruct the original sense 'to collect together (all the parts)' > 'to grasp, understand (the whole picture of an object or a situation)' in which case inter- means 'to collect as a whole. The Latin com-prehendere 'understand' (lit. 'grasp together') is a partial semantic parallel for this reconstruction. This parallel is not exact in both parts: legere means 'collect' whereas prehendere means 'grasp'; com- means 'with', whereas inter- means 'between'. Nevertheless, both have the same etymological sense - the idea of first physically collecting and then mentally piecing together an object as a whole in all its parts.

I think there is no need to choose between a. and b. In this particular case both are only two subsequent stages in the semantic evolution of the compound. Thus, I propose that intellegere might have meant first 1. 'to choose between', 'to notice, discern'. This stage is well attested in such contexts as intellecturis auribus uti Ov.; vestigia hominum intellegi a feris Plin.; ut aquae salsae non intellegatur Sapor Plin.; nullos intellegit ignes Ov.; cum frigus contra temporis consuetudinem intellexeris Colum. (the examples are from Georges 1913, 2655); Which one of the senses does inter- in intellegere belong to?

The second stage is 'to collect together (all the parts)' > 'to grasp, understand (the whole picture of an object or a situation)' which is attested in such contexts as intellexi ex tuis litteris, te audisse Cic.; intellexti 'right', 'you get it right' Ter. 'understand', 'know': propositio ex se intellegitur 'is self-explanatory'.

\section{Conclusion}

The dictionary entry for the Latin prefix inter- should be based on the function of this prefix within the compounds with this component, which allows to reduce the 15 main senses (described in OLD) to the basic two ones. Either sense of the prefix depends on a situation described with the compound: a. the situation of dividing space (group a, examples 1-11, most of them are transitive (except for 7-8) or used as transitive with a countable object) or b. a situation of connected space (group b, examples 12-15, most of them are transitive with uncountable object, one verb expresses a reciprocal action (example

${ }^{3}$ During my presentation at the international philological conference which was held in St. Petersburg State University on the March 2018, E. V.Zheltova proposed an idea that the Latin intellegere was formed in accordance with the same semantic model as the Latin comprehendere and thus its original meaning was 'to grasp together', which came to mean 'to understand'. 
14) or space of an object to work on (15)). Because of the nature of their lexical meaning (intransitive verbs of state), some verbs can have either sense depending on the context (group c, examples 16-19). Three of them (20-22) have the prefix inter-in the sense of division and form pairs of compounds (an intransitive verb of state interire - a verb of action interimere, interficere). Some of them have archaic cognate in other Indo-European languages which speaks for the old age of these compounds that form a pair (an intransitive verb of state interire, perire - a verb of action interimere, interficere). The verb intellegere has two senses as different stages of its semantic development: 1. 'to choose between', 'to notice, discern' and 2. 'to collect together (all the parts)' > 'to grasp, understand (the whole picture of an object or a situation)'. Which sense develops in which case (or both develop) depends on the lexical properties of the verb: on its transitivity and on the type of an object it can have (countable or uncountable).

\section{References}

Apte V.S. The Practical Sanskrit-English Dictionary. Revised and enlarged edition. I-III. Poona, Prasad Prakashan, 1957-1959.

Ernout A., Meillet A. Dictionnaire étymologique de la langue latine. Paris, Klincksieck, 2001.

Georges K. E. Ausführliches lateinisch-deutsches Handwörterbuch. Hannover - Leipzig, Hahn, ${ }^{8} 1913$.

Rix H. et al. Lexikon der indogermanischen Verben. Die Wurzeln und ihre Primärstammbildungen. Wiesbaden, ${ }^{2} 2001$.

Mayrhofer M. Etymologisches Wörterbuch des Altindoarischen. I-III. Heidelberg, Carl Winter Universitätsverlag, 1992.

de Vaan M. Etymological Dictionary of Latin and the Other Italic Languages. Leiden - Boston, Brill, 2008. Walde A., Hoffmann J. B. Lateinisches etymologisches Wörterbuch. Heidelberg, ${ }^{3} 1938-1954$.

Received: February 23, 2019

Accepted: April 22, 2019 